\title{
THE EFFECTIVENESS OF RECIPROCAL TEACHING LEARNING MODEL TOWARD RESULT OF MATHEMATICS LEARNING OUTCOMES IN STUDENTS CLASS VII OF SMP NEGERI 2 SLEMAN
}

\author{
Erni Andriyania, Uswatun Khasanah ${ }^{\mathrm{b}}$ \\ Program Studi Pendidikan Matematika Universitas Ahmad Dahlan \\ Jalan Ring Road Selatan, Tamanan, Banguntapan, Bantul Yogyakarta \\ akimerni06@gmail.com, ${ }^{\mathrm{b}}$ uswatun.khasanah@ pmat.uad.ac.id
}

\begin{abstract}
The dominant model of learning that teachers lead students more passive in participating in learning activities, especially mathematics. So, that students become less familiar with the material describe teachers. This affects the result of students in mathematics learning. This study aims to determine the effectiveness of the Reciprocal Teaching-learning model toward the result of mathematics learning outcomes in students class VII. The population in this study is the seventh-grade students of SMP Negeri 2 Sleman in the academic year 2015/2016 which consists of 5 classes. The sampling technique using a purposive sampling technique and obtained class VII C as an experimental class and class VII B as a control class. The data was collected using documentation and the test method. The data analysis technique used analysis prerequisites of normality test, homogeneity test, and hypothesis testing. The result showed that (1) there is a different learning outcomes between learning mathematics using learning model Reciprocal Teaching with learning mathematics using learning model Ekspositori. It's based on two hypothesis test obtained $t^{\prime}$ count $=3,9721$ and $t_{\text {table }}=2,038$ with significance level of $5 \%$ and the degrees of freedom, respectively $n_{1}-1=30$ and $n_{2}-1=31$, which meanings $t_{\text {count }}^{\prime}>t_{\text {table }}$, and than $H_{0}$ is rejected and $H_{1}$ accepted. (2) Learning mathematics using learning model Reciprocal Teaching is more effective than learning mathematics using learning model Ekspositori through mathematics learning outcomes on seventh-grade students of SMP Negeri 2 Sleman in the academic year of 2015/2016. It is based on the one hypothesis test obtained $t_{\text {count }}^{\prime}=0,9057$ dan $t_{\text {table }}=2,0386$ with significance level of $5 \%$ and the degrees of freedom, respectively $n_{1}-1=$ 30 and $n_{2}-1=31$, which means $t_{\text {count }}^{\prime}>t_{\text {table }}$, and than $H_{0}$ is rejected and $H_{1}$ accepted.
\end{abstract}

Keywords: effectiveness, Reciprocal Teaching, Ekspositori.

\section{INTRODUCTION}

Education plays an important role in human survival. In the National Education System Law Number 20 Year 2003, Chapter VI article 13 paragraph (1) states that the education pathway consists of complementary formal, non-formal and informal education. Formal education is education carried out in schools and has a level. Non-formal education is education conducted outside formal education. Whereas informal education is education carried out in the family and community environment. With the rapid development of Science and Technology (IPTEK), high-quality Human Resources (HR) are needed so that they can compete in the coming global era. The large number of students who think mathematics is difficult makes teachers must be able to create varied learning models in teaching. Because each student has a different way of learning and responding to problems in mathematics. Therefore, a teacher must be able to recognize how students learn in order to apply good and effective learning models in teaching in class. Because with the application of the right learning model, the success rate will also be higher.

Based on the results of observations some students were not active in the classroom when given the practice questions. Students who work on problems in front of the class are usually the same students. It will also lead to boredom in learning activities and will affect student learning outcomes. The process of teaching and learning mathematics is expected to be more effective and enjoyable so that students feel happy and comfortable in learning. In this case, also the teacher can choose a learning model that is suitable for the subject matter so that students are interested in learning mathematics. Basically, each learning model has advantages and disadvantages of each. Therefore, the selection of learning models adapted to the material to be taught. 
There are various kinds of learning models that can be applied in teaching and learning activities and are expected to improve student learning outcomes. Shoimin, Aris (2014: 153-155) states that: Reciprocal Teaching is a learning model in the form of activities to teach material to friends. In this learning model students act as "teachers" to deliver material to their peers. Meanwhile, the teacher plays a role as a model who becomes a facilitator and supervisor who conducts scaffolding. Scaffolding is guidance given by people who know better to people who don't know or don't know. According to Taranto (2009: 96) states that: Reciprocal Teaching is a model of teaching students about learning strategies. Reciprocal Teaching is mainly developed to help teachers use cooperative learning dialogues to teach reading comprehension independently in class. Some of the advantages of the Reciprocal Teaching-learning model according to Shoimin, Aris (2014: 156), namely:

1. Develop student creativity.

2. Foster cooperation between students.

3. Students learn by understanding

4. Because learning by understanding, students do not easily forget.

5. Students study independently.

6. Students are motivated to learn.

7. Growing student talent, especially in speaking and developing attitudes.

8. Students pay more attention to the lesson because they live by themselves.

9. Cultivate the courage to think and speak in front of the class.

10. Train students to analyze problems and draw conclusions in a short amount of time.

11. Fostering an attitude of respect for teachers because students will feel the teacher's feelings when conducting learning especially when students are busy or not paying attention.

12. It can be used for large subject matter and limited time allocation.

The learning steps use the reciprocal teaching-learning model according to Shoimin, Aris (2014: 154), namely:

1. Group students and group discussions. Students are grouped into several small groups. The classification of students is based on the ability of each student. It is intended that the abilities of each group formed are almost the same. After the group is formed, they are asked to discuss the worksheet that has been received.

2. Make a question (Questing Generation). Students make questions about the material discussed then deliver it to the class.

3. Present the results of group work. The teacher asks one group to explain their findings in front of the class, while the other group responds or asks about the findings presented.

4. Clarifying problems (Clarifying). Students are given the opportunity to ask questions about material that is considered difficult for the teacher. The teacher tries to answer by asking inducement questions. In addition, the teacher held a question and answer related to the material being studied to find out the extent of students' understanding of the concept.

5. Provide practice questions that contain development questions (Predicting). Students get practice questions from the teacher to do individually. This problem contains a matter of developing the material to be discussed. This is intended so that students can predict what material will be discussed at the next meeting.

6. Summing up the material being studied (Summarizing). Students are asked to save the material that has been discussed.

According to Sanjaya, Wina (2006: 179) expository learning models are models that emphasize the process of delivering material verbally from a teacher to a group of students with the intention that students can master the subject matter optimally. According to Roy Killen in Sanjaya, Wina (2006: 179) states that: This expository learning model is called the direct learning model (direct instruction). Why? because in this model the subject matter is delivered directly by the teacher. Students are not required to find the material. The subject matter as if it's already been made. Because the Expository learning model 
emphasizes the process of speaking, it is often also called the "Chalk and Talk" model. The advantages of expository learning models according to Hamruni (2009: 128) are:

1. With the expository learning model the teacher can control the sequence and breadth of the learning material, so the teacher can know to what extent the students master the subject matter delivered.

2. Expository learning models are considered to be very effective if the subject matter that must be mastered by students is quite extensive, while the time available for learning is limited.

3. Through expository learning models in addition to students can hear through narration (lecture) about a subject matter, also at the same time, students can see or observe (through demonstration).

4. This expository learning model can be used for large numbers of students and class sizes.

The steps in applying the Expository learning model according to Hamruni (2009: 123) are:

1. Preparation. The preparation phase deals with preparing students to receive lessons. The objectives to be achieved in preparing are to invite students out of a passive mental state, arouse students 'motivation and interest to learn, stimulate and arouse students' curiosity, and create an open learning atmosphere.

2. Presentation. The presentation step is the step of delivering the subject matter in accordance with the preparations that have been made. What every teacher must think about in this presentation is how to make the subject matter easily captured and understood by students.

3. Connection. This step is the step of linking subject matter with student experience or with other things that enable students to grasp its relevance in the structure of knowledge they already have. Conclusions Concluding is the stage for understanding the core of the subject matter that has been presented. The concluding step is a very important step in the Expository model because through this step students will be able to take the essence of the presentation process.

4. Application. The application step is a step for students' abilities after they have listened to the teacher's explanation. Through this step, the teacher will be able to gather information about the mastery and understanding of subject matter by students. Techniques that can be done in this step include making assignments relevant to the material and by providing appropriate tests of the material.

The objectives to be achieved in this study are as follows.

1. To find out whether or not there are differences in student learning outcomes in mathematics using the Reciprocal Teaching-learning model with student learning outcomes in mathematics using the expository learning model of students of SMP Negeri 2 Sleman in the 2015/2016 Academic Year.

2. To find out more effective learning between the Reciprocal Teaching-learning model and mathematics learning using the Expository learning model for grade VII students of SMP Negeri 2 Sleman in the 2015/2016 Academic Year.

\section{METHODS}

This research is an experimental research type. The population in this study is the seventh-grade students of the even semester SMP Negeri 2 Sleman District in the 2015/2016 academic year consisting of 5 classes namely VII A, VII B, VII C, and VII E, VII F. In the study this, sample selection using Purposive Sampling. According to Sugiyono (2012: 124), "Purposive Sampling is a sampling technique with certain considerations." This technique is done by direct appointment of a population consisting of 5 classes so that class VII C is obtained as an experimental class that will be given learning by learning models Reciprocal Teaching and class VII B as a control class. Whereas the trial class was carried out in class VII A. Data collection techniques used were documentation and test techniques. Documentation techniques were used to determine students' initial mathematical abilities before an experiment was carried out, while the test techniques were used to evaluate student mathematics learning outcomes. The research instrument tests used were validity, different power tests, and reliability tests. Then for the prerequisite test analysis used is the normality test and homogeneity test. Data analysis for hypothesis testing uses two-party hypothesis testing and one-party hypothesis testing. 


\section{RESULTS AND DISCUSSION}

\section{Initial Ability}

The initial ability score is obtained from the UTS Even Semester. The results of the experimental class are the highest value of 90 , the lowest value of 48 , an average of 67.9356 , a standard deviation of 11.7017 and a variance of 136.9290. While the results of the control class with the highest value of 90 , the lowest value of 20 , an average of 64.3750 , standard deviation of 18.7922 and variance of 353.1452 .

Table 1. Normality Test Results Initial Capability Value

\begin{tabular}{|c|c|c|c|c|c|}
\hline Class & $\chi_{\text {count }}^{2}$ & $\chi_{\text {table }}^{2}$ & Level & Df & Info \\
\hline Experiment & 0,5810 & 7,8147 & $5 \%$ & 3 & Normal \\
\hline Control & 5,1095 & 7,8147 & $5 \%$ & 3 & Normal \\
\hline
\end{tabular}

Based on the results of the normality test the meaningful initial ability value $\chi_{\text {stat }}^{2}<$ $\chi_{\text {table }}^{2}$ so it can be concluded that the initial ability of the experimental class is normally distributed data and on a meaningful control class $\chi_{\text {count }}^{2}<\chi_{\text {table }}^{2}$ so it can be concluded that the initial ability of the control class is normally distributed data.

Based on the homogeneity test results the initial ability value is obtained $\chi_{\text {count }}^{2}=6,5685$ and $\chi_{\text {table }}^{2}=3,8415$ at a significant level of $5 \%$ and a degree of freedom 1 . Which means $\chi_{\text {count }}^{2}>X_{\text {table }}^{2}$ so it can be concluded that the sample has a non-homogeneous variance.

Based on the results of the hypothesis test that uses the similarity of the average initial ability values obtained $t_{\text {count }}=0,9057$ and $\frac{w_{1} t_{1}+w_{2} t_{2}}{w_{1}+w_{2}}=2,0386$ so that $-2,0386<t^{\prime}<2,0386$, which means $\mathrm{H}_{0}$ is accepted. So, it can be concluded that there is no difference in the students' initial ability scores between class VII C (Experiment) and class VII B (Control) of SMP Negeri 2 Sleman in the 2015/2016 Academic Year.

\section{Mathematics Learning Outcomes}

The results of the test scores of mathematics learning outcomes from the experimental class with the highest score of 100 , the lowest value of 80.0000 , an average of 93.33333 , a standard deviation of 6.2063 and a variance of 38.5185. While the results of the control class with the highest value of 93.33300 , the lowest value of 40.0000 , an average of 83.9583 , a standard deviation of 11.2144 and a variance of 125.7616 .

Table 2. Normality Test Results Mathematics Learning Outcomes Test Results

\begin{tabular}{|c|c|c|l|l|c|}
\hline Class & $\chi_{\text {count }}^{2}$ & $\chi_{\text {table }}^{2}$ & Level & Df & Info \\
\hline Experiment & 2,0678 & 5,9915 & $5 \%$ & 2 & Normal \\
\hline Control & 2,4149 & 3,8415 & $5 \%$ & 1 & Normal \\
\hline
\end{tabular}

Based on the results of the normality test the test results of learning outcomes that in the experimental class which means $\chi_{\text {count }}^{2}<\chi_{\text {table }}^{2}$ so that it can be concluded that the test scores of the experimental class learning outcomes are normally distributed data and in the control class which means $\chi_{\text {count }}^{2}<\chi_{\text {table }}^{2}$ so it can be concluded that the test scores of the control class learning outcomes are normally distributed data.

Based on the homogeneity test results the test results obtained $\chi_{\text {count }}^{2}=11,4578$ and $\chi_{\text {table }}^{2}$ $=3.8415$ at a significant level of $5 \%$ and degrees of freedom 1 . Which means $\chi_{\text {count }}^{2}>\chi_{\text {table }}^{2}$ so that it can be concluded that the sample has a variance that is not homogeneous.

\section{Hypothesis Testing}

Based on the results of the two-party hypothesis test obtained that the value $t_{\text {count }}^{\prime}=$ 3,9721 and $\frac{w_{1} t_{1}+w_{2} t_{2}}{w_{1}+w_{2}}=2,0384$ at a significant level of $5 \%$ and degrees of freedom respectively $n_{1}-1=30$ and $n_{2}-1=31$ which mean $-2,0384<t^{\prime}>2,0384$, so $\mathrm{H}_{0}$ is rejected and $\mathrm{H}_{1}$ is 
accepted. Thus, there are differences in mathematics learning outcomes between students who use the Reciprocal Teaching-learning model and the Expository learning model.

Based on the results of the one-party hypothesis test obtained that the value $t_{\text {count }}^{\prime}=$ 3,9721 dan $\frac{w_{1} t_{1}+w_{2} t_{2}}{w_{1}+w_{2}}=1,698$ at a significant level of $5 \%$ and degrees of freedom respectively $n_{1}-1=30$ and $n_{2}-1=31$ which means $t_{\text {count }}^{\prime} \geq \frac{w_{1} t_{1}+w_{2} t_{2}}{w_{1}+w_{2}}$, so $\mathrm{H}_{0}$ is rejected and $\mathrm{H}_{1}$ is accepted. Thus, learning mathematics using the Reciprocal Teaching-learning model is more effective than learning that uses the Expository learning model of mathematics learning outcomes for Grade VII students of SMP Negeri 2 Sleman even semester 2015/2016 Academic Year.

\section{CONCLUSION}

Based on the results of research and discussion, it can be concluded that:

1. There are differences in students' mathematics learning outcomes using the Reciprocal Teachinglearning model and the Expository learning model in grade VII students of SMP Negeri 2 Sleman even semester 2015/2015 academic year.

2. Mathematics learning of students who use Reciprocal Teaching-learning models is more effective than Expository learning models in VII grade students of SMP Negeri 2 Sleman even semester 2015/2015 academic year.

\section{REFERENCES}

Shoimim, Aris. 2014. 68 Model Pembelajaran Inovatif dalam Kurikulum 2013.Yogyakarta: Ar-Ruzz Media.

Trianto. 2009. Model-Model Pembelajaran Inovatif Berorientasi Konstruktivistik. Jakarta:Prestasi Pustaka.

Sanjaya, Wina. 2006. Strategi Pembelajaran Berorientasi Standar Proses Pendidikan. Jakarta: KENCANA.

Hamruni. 2009. Strategi dan Model-Model Pembelajaran Aktif-Menyenangkan. Yogyakarta: Fakultas Tarbiah UIN Sunan Kalijaga. 